\title{
HERITAGE ON DEMAND: UNESCO INTANGIBLE CULTURAL HERITAGE INITIATIVE IN CROATIAN CONTEXT
}

\author{
Marijana Hameršak \\ Institute of Ethnology and Folklore Research, Croatia \\ e-mail:marham@ief.hr \\ Iva Pleše \\ Institute of Ethnology and Folklore Research, Croatia \\ e-mail:piva@ief.hr
}

\begin{abstract}
The $\operatorname{article}^{1}$ critically engages with the articulations and manifestations of a UNESCO initiative for the safeguarding of so-called intangible cultural heritage in Croatian context in the first years of the active Croatian implementation of the Convention for the Safeguarding of the Intangible Cultural Heritage (2009-2013). It presents the intersections of a UNESCO initiative with past and present ethnology and folklore research in Croatia. Though one might get the impression (not entirely unfounded) that the project of protecting or safeguarding intangible heritage within the Croatian context first and foremost constitutes a global, imported product, the notion of protecting or safeguarding intangible cultural heritage can also be traced in the history of Croatian ethnology, folkloristics, art conservation, legislation, and folklore festivals production. A strong tendency to transform culture into a slick product can be seen as the main or only 'innovative' aspect of transmitting the old concepts into the contemporary framework of the UNESCO initiative. It seems like this aspect makes it easier for everyone involved - state administration and experts and those to whom a given cultural practice 'belongs' - to ignore 'the side effects' of the UNESCO initiative and the processes of its implementation that are discussed in the article. These side effects, perhaps not so visibly, concern society as a whole, and more directly local communities, as well as our specific professions and disciplines: ethnology and folkloristics.
\end{abstract}

Keywords: Convention for the Safeguarding of the Intangible Cultural Heritage, Croatia, ethnology and folkloristics, heritage production, intangible cultural heritage, UNESCO 


\section{INTRODUCTION: STAGING INTANGIBLE CULTURAL HERITAGE}

'Inherited tradition in counterpoint to modernity' and none other than 'man in the centre of things' were key elements in the ceremony organised to mark Croatia's entry into the European Union, a celebration held in the main square in Zagreb on the night of 30 June $2013 .{ }^{2}$ As stated in the promotional materials prepared for the occasion, the programme was built around 'the values of Croatia's protected cultural property, including the UNESCO Representative List', and strove to emphasise 'Croatia's representative qualities in the areas of music, literature, and science'. In the aforementioned materials the UNESCO Representative List, which grew out of the 2003 Convention for the Safeguarding of Intangible Cultural Heritage, refers to the area of so-called intangible cultural heritage, or what was once known as folklore, traditional immaterial culture, folk art, popular traditions, or some other more or less cognate and similar terms, all of which are closely and probably inextricably linked to ethnology and folkloristics. In previous years, a 'new' intangible cultural heritage of humanity, as it is referred to in the UNESCO Convention, has periodically been added to the List. Annual carnival bell ringers' pageant, the spring procession of Ljelje/Kraljice (Queens), Nijemo kolo, the silent circle dance, and traditional manufacturing of children's wooden toys: these are, to use the terminology of the Convention, some of Croatia's elements which found their place on UNESCO Lists and ultimately in the celebration held to mark Croatia's accession into the European Union, along with their supposed antipodes: modernity and so-called high art. At times these elements were at the forefront of the programme, while at other times their inclusion was almost imperceptible, as in the case of the aforementioned wooden toys which were, together with plastic rakes, given to child actors to 'play' with during the Croatian Radiotelevision Symphony Orchestra and the Symphonic Wind Orchestra of the Croatian Armed Forces' occasional performance of Sunčana polja (Sunny Fields) by Croatian composer Blagoje Bersa.

Whether the celebration was a 'conceptual mixed bag', 'crammed with significant features of Croatian tradition and identity which "must be presented" to the world' (Prnjak 2013), or perhaps 'superbly executed within the set form' (Matasović 2013) is not the issue here. We are not interested in whether the ducats on the Ljelje's costumes were authentic or fake, whether the songs and dances were performed by indigenous bearers of cultural elements or trained members of folklore groups from Zagreb and professional dancers, or whether the performers' costumes were well or poorly reconstructed. The question of whether experts on traditional culture were consulted in the process of select- 
ing and shaping individual performance pieces, or whether the programme included performances that were choreographed long ago and previously staged on numerous occasions, together with descriptions of representative elements of intangible cultural heritage already in circulation (in reality promotional materials from the official website of UNESCO and other similar websites), is not relevant here.

In this context, the abovementioned celebration of Croatia's entry into the EU might provide us with something else. Due to the fact that its content is intertwined with traditional culture, the celebration programme provides us with an opportunity to draw comparisons with the UNESCO initiative for the protection or safeguarding of intangible cultural heritage. The possibilities for drawing comparisons are numerous: one such comparison might focus on the problem of representation as well as selectivity, that is, choosing certain elements for presentation on stage or inclusion on the List over others; additional comparisons might be concerned with the role of authority (the director or folklore expert) and the extent to which the procuring party (state administration) exerts influence on this type of undertaking. Possible comparisons might also focus on means of expressing national pride, presenting a diverse but nonconflicting (polite and spruced-up) national identity, as well as on the role of the idyllic image of dancing peasants in this type of representation.

However, it was something else that prompted us to engage in a discussion of the EU accession ceremony in a text which, adopting a focused local perspective, presents disputes which, to be sure, have parallel articulations the world over. Our main incentive was the issue of whether or not the whole of UNESCO's current project for the protection or safeguarding of intangible cultural heritage - which includes innumerable meetings, conferences, consultations, workshops, reports, feasibility studies, petitions, travels, financing ${ }^{3}-$ is in actuality a performance, a process that ultimately turns select elements into a part of ceremonial celebrations and tourist offers (or maintains the existing status of these elements while adding a brand new UNESCO certificate to them), thus turning them into a 'salvationist framework' (Pofuk 2013) for developing cultural and artistic programmes on stage, utilizing them for presentation purposes, as pretty pictures in catalogues and on websites - in short, reducing them to mere products, despite explicit claims of the abovementioned Convention (cf. UNESCO 2003, Preamble; Art. 1, Art. 2, Art. 11 and Art. 15) that its focus is on the local community and UNESCO's noble intentions to give the community a central position and active part in the process of preserving its own culture in a living context, so that, having been empowered, that same community can take the fate of its own culture into its own hands. Bearing contemporary social tendencies and imperatives in mind, the commodification 
of culture is by no means unexpected, but we would like to point out that it is potentially devastating to the self-perception of communities, individuals, professions and institutions participating in this whole process, to self-perceptions that presuppose a higher degree of complexity and substance.

After all, the main problem with the UNESCO project and other similar projects lies with their side effects, which is to say conflicts, encroachments, and losses, which are already numerous (cf., e.g., Mezey 2007; Mountcastle 2010; Nikočević 2012; Noyes 2006). It is precisely these unsettling (to say the least) side effects - revealed on the margins of the great UNESCO project, and even there by participants or observers speaking in low or hushed voices - that were the incentive for this text, created in collusion with a globally increasing group of texts which are concerned with the side effects and neuralgic points of the UNESCO project and similar endeavours, and address some of the following questions (cf., e.g., Bendix 2009; Bortolotto 2009; Hafstein 2007; Leimgruber 2010; Tsitsishvili 2009): What happens when people begin to perceive their everyday life or part of their lives as heritage? What role does the concept of ownership - a key problem which stems from the Convention implementation but is entirely ignored by that same Convention which makes no attempt to solve it - have within the UNESCO project? What is the role of international political and other organisations, national state administration, and experts in this process? What is the role of the community, and what exactly does the term 'community' refer to? Who is included in the process, who has been overlooked and who, perhaps intentionally, excluded and why? Which practices of inscription onto UNESCO Lists (which seems to be the most important, at times even the only point of the Convention) are perceived by the public? How is culture bought and sold on the political and economic market?

These questions are also essential for understanding the problems which are becoming increasingly prominent in the Croatian context and form the core of following local dilemmas we read about or infer from media reports, and quote or paraphrase in this article. ${ }^{4}$ Is traditional Ojkanje singing a Croatian, Orthodox, Serbian or Balkan tradition? Is Ganga singing a 'privilege' reserved only for inhabitants of its native region in Croatia, or can it also be performed by Croats living abroad? Why does it matter whether one or all groups of Zvončari (described as annual carnival bell ringers' pageant) are inscribed onto the UNESCO List? Can Klapa multipart singing as a stadium attraction be considered a part of the UNESCO heritage, or is this status reserved only for authentic a cappella Klapa multipart singing? Does the inscription of the Sinjska Alka on the List imply its official recognition as the world's oldest chivalric tournament? Is the UNESCO initiative in Croatia in fact the project of a single Minister of Culture? 


\section{CONVENTION FOR THE SAFEGUARDING OF INTANGIBLE CULTURAL HERITAGE}

In previous years, the term 'intangible cultural heritage' has become increasingly present in public discourse in Croatia and elsewhere, in a cultural and scholarly context, but also in the context of tourism and even politics. The reason for this is the aforementioned UNESCO initiative and its key document, the Convention for the Safeguarding of Intangible Cultural Heritage (UNESCO 2003). Among other things, the aim of the Convention is to raise awareness of the importance of intangible cultural heritage, ensure the vitality of its local and national elements, and thus indirectly influence the safeguarding of cultural diversity and human creativity, that is, intercultural dialogue and respect (cf. UNESCO 2003, e.g. Preamble; Art. 1; Art. 2). Responsibility for protecting and safeguarding (though loosely defined) lies primarily with the States Parties, which therefore identify and define elements of intangible culture, create and update Lists, and take necessary steps towards creating and implementing suitable public policies and measures (cf. UNESCO 2003, Art. 11-15). Setting the continuous negotiation process conducted on all levels, and possible modes of granting direct assistance to the States aside (cf. UNESCO 2003, Art. 18-24), it might be said that the very act of awarding certificates or inscribing elements on the two Lists - the Representative List of the Intangible Cultural Heritage of Humanity and the List of Intangible Cultural Heritage in Need of Urgent Safeguarding ${ }^{5}$ - as well as adding them to the Register of Best Safeguarding Practices, constitute virtually the only measures UNESCO itself is obligated to implement.

As has already been noted on numerous occasions, a long, perhaps even several-decades-long negotiation and consulting process which takes place on an international level (cf., e.g., Aikawa 2004) forms the background of the 2003 Convention. The Convention is immediately preceded by the Recommendation on the Safeguarding of Traditional Culture and Folklore (UNESCO 1989), the first official document specifically aimed at safeguarding what will later be termed intangible cultural heritage, as well as the Masterpieces of Oral and Intangible Heritage of Humanity programme, inaugurated in 1998. The Convention itself is sometimes interpreted as an amendment of sorts, but also as the first significant attempt to move away from the influential and much older UNESCO Convention Concerning the Protection of the World Cultural and Natural Heritage (UNESCO 1972), the focus of which was the protection of monuments, groups of buildings or sites, in other words what is nowadays termed tangible heritage. A key critical issue of the 1972 Convention is its Western perception of heritage which has, in the process of implementing the 
Convention, resulted in the fact that the status of 'heritage of humanity' is for the most part granted to urban sites and monuments of high culture, as well as landscapes, the majority of which are located on the northern hemisphere (cf. Kuutma 2013 [2012]: 24). On the other hand, it has often been pointed out that the notion that intangible cultural heritage needs protecting and safeguarding, and consequently the adoption of the 2003 Convention, were strongly influenced by the assumption that globalisation has destructive, even disastrous effects on intangible heritage. At the same time, analyses that would question the adoption of this particular UNESCO Convention from the perspective of UNESCO's wider re-orientation towards promoting, at times even directly serving market interests, in some cases also via partnerships with transnational corporations (cf. Fawcett 2009), are yet to be carried out. Namely, one cannot help feeling that the UNESCO programme is potentially, in some cases also literally, directing culture towards so-called market challenges. By determining, singling out, listing, in other words evaluating culture as representative or endangered elements of intangible culture, for which the responsibility is not delegated to anyone and at the same time is delegated to everyone (humanity, countries, communities, and individuals alike), by its very text, the Convention for the Safeguarding of Intangible Cultural Heritage defines segments of culture which - in the name of various agendas, ranging from strengthening the national tourist or other offer to stimulate the self-sustainability of local communities via similar activities, with a dose of entrepreneurial skill - can, when necessary, be treated as resources and products (cf., e.g., KirshenblattGimblett 2006: 195; Labadi 2013: 141-142). Considering the period in which this process takes place, it seems illusory to expect that the economic coding of yet another sphere of human activity, the culture of 'ordinary' people, will in the long run truly signify something more than the strengthening of a system which values those same people in terms of their necessity to keep the wheels of capital accumulation and circulation turning as effectively as possible. As Walter Leimgruber expressed clearly in the closing remarks of his article on Switzerland and UNESCO Convention:

Should current trends continue, the process triggered by the UNESCO Convention will generate isolated, immobilized, but 'pretty' intangible cultural forms that will become popular tourist attractions. However, these forms have little to do with the lifeways of actual communities. Intangible culture instead will become as decontextualized as the objects of material culture placed behind glass cases, on display in our museums. (Leimgruber 2010: 186) 


\section{THE NOTIONS AND MANIFESTATIONS OF PROTECTING AND SAFEGUARDING IN THE PAST AND PRESENT CROATIAN CONTEXT}

Croatia ratified the UNESCO Convention for the Safeguarding of Intangible Cultural Heritage already in 2005 (cf. Zakon 2005), thus adding to the number of countries necessary for the Convention to enter into force in 2006. The promptness that characterises Croatia's acceptance of the Convention is one of many indications of just how willing its state administration - which has with that express purpose in mind put entire administrative and expert-scientific machineries in motion - is to take such a step.

Though one might get the impression (not entirely unfounded) that the project of protecting or safeguarding intangible heritage within the Croatian context first and foremost constitutes a global, imported product, the notion of protecting or safeguarding intangible cultural heritage can also be traced in the history of Croatian ethnology, folkloristics, art conservation, and legislation. Namely, contributions (in the second part of the twentieth century also prompted by international organisations and bodies) dealing with various levels of 'protecting' (from descriptions and regulations, through inventory-making to conservation protection) what is nowadays termed intangible cultural heritage, stemmed from those precise areas.

In the Croatian context, intangible culture has been codified since the adoption of the 1999 Law on the Protection and Safeguarding of Cultural Property. Still in force today, this Law also defines 'immaterial forms and instances of man's spiritual creation in the past' (Zakon 1999, Art. 2), or 'intangible cultural property' (Zakon 1999, Art. 9) as a special type of cultural property. What is more, one of its mechanisms - the Register of Cultural Property of the Republic of Croatia (or rather the segment of the Register which refers to intangible cultural property) - has taken on the role of a national inventory of intangible cultural heritage, an instrument set out in the UNESCO Convention (UNESCO 2003, Art. 12), and nowadays functions as the entry point for Croatian nominations to UNESCO Lists. Namely, entry into the Register is a prerequisite for being nominated to one of these Lists. Paradoxically enough, legal definitions require the Register to include intangible cultural property which is (with the exception of linguistic phenomena) explicitly oriented towards the traditional, folklore and folk, which is at odds with the wider definition provided by UNESCO. In other words, Croatia can nominate such elements of intangible culture to UNESCO Lists that are manifested as 'language, dialects, speech, and toponyms, along with all kinds of oral literature; folklore production in the 
areas of music, dance, traditions, games, rituals, and social practices, along with other traditional folk values; traditional skills and craftsmanship' (Zakon 1999, Art. 9), while the much wider definition set forth in the UNESCO Convention describes intangible culture as '(a) oral traditions and expressions, including language as a vehicle of the intangible cultural heritage; (b) performing arts; (c) social practices, rituals and festive events; (d) knowledge and practices concerning nature and the universe; (e) traditional craftsmanship' (UNESCO 2003, Art. 2, § 2). ${ }^{6}$

Although the term 'intangible cultural property' was introduced into legislative regulation in 1999, the means of safeguarding and protecting intangible cultural heritage had been discussed in the Croatian Ethnological Society more than three decades earlier. As elsewhere, it was the part of, as Laurajane Smith calls it, Authorised Heritage Discourse of a time or professional discourse 'involved in the legitimization and regulation of historical and cultural narratives, and the work of that these narratives do in maintaining or negotiating certain societal values and the hierarchies that these underpin' (Smith 2012). Reports on the work of the Croatian Ethnological Society thus contain information about the establishment of the Ethnographic Commission for Museum and Conservation Work in 1962 (Milićević 2009: 16) which was, among other things, charged with the task of proposing alterations and amendments to the 1960 Law on the Protection of Monuments of Culture, 'with reference to intangible traditional heritage' (Škrbić Alempijević \& Oroz 2009: 70). That the issue of protecting intangible aspects of traditional culture was of particular interest to individual members of the Commission - conservators and museologists - is seen in the fact that two years later an independent Commission for Detecting Possibilities for Protecting Intangible Culture was formed (Škrbić Alempijević \& Oroz 2009: 70). ${ }^{7}$

On a somewhat similar trail is also the manuscript of a lecture, given by Croatian ethnologist Dunja Rihtman-Auguštin (1982), at that time acting as representative of the Yugoslav Government in the UNESCO Committee of Governmental Experts (Rihtman-Auguštin 1984: 27). Though pursuing other research interests in her scholarly work, Rihtman-Auguštin gave the aforementioned lecture at a conference dedicated to issues of folklore protection in the Balkan countries. In the lecture, Rihtman-Auguštin presented the Yugoslav and wider professional community with the necessity for and means of protecting folklore, a topic that had also been discussed in Paris the previous year, at the meeting of said UNESCO Committee in which she herself took part. Protection is presented as a process which has to bring together two perspectives: an ethnological-folkloristic perspective, which includes the processes of safeguarding, collecting, organizing, and archiving, publishing, studying, and 
applying, but also a legal perspective concerned with protection from 'inappropriate uses of folklore creations', commercialization, and other forms of exploitation (Rihtman-Auguštin 1982: 2, 5). Furthermore, Rihtman-Auguštin suggests that a 'register of institutes, bureaus, museums, public and private collections', in other words, 'a database of traditional culture and folklore' (Rihtman-Auguštin 1982: 7-8) be formed, first on the level of individual republics of the former Federal Republic of Yugoslavia, and then on the level of the Republic as a whole, with the tendency of expanding, to include the entire Balkan area. The Croatian Ethnological Society and the Institute of Folklore Research (nowadays: the Institute of Ethnology and Folklore Research) began work on 'a database of folklore and traditional culture in Croatia and Yugoslavia' (Rihtman-Auguštin 1984: 23), which resulted in a register containing more than 100 institutions in Croatia, dedicated to collecting and safeguarding materials related to traditional culture and folklore (s.n. 1986; cf. also Škrbić Alempijević \& Oroz 2009: 75). Plans for incorporating 'the information system of materials regarding traditional culture and folklore into the international system implemented by UNESCO', networking with institutions with similar databases, and continuing with the process of analysing folklore materials with the aim of incorporating them into the aforementioned system (Rihtman-Auguštin 1984: 23) were not realised. The project led to the publication of Institutions that Collect and Preserve Materials on Traditional Culture and Folklore in the Federal Republic of Croatia (s.n. 1986), as well as archival materials which include completed forms from individual Yugoslav institutions and are kept in the Archives of the Institute of Ethnology and Folklore Research in Zagreb (Turčin 1982-1986).

Efforts aimed at creating a database that might be linked to the documentation of (traditional) culture as one of many important activities within Croatian ethnology and folkloristics in general, and activities developed independently from UNESCO and its initiatives, may be subsumed under the term of so-called salvation ethnology, anthropology or ethnography. The term refers to specific initial stages of a given discipline or disciplines, marked (both in Croatia and elsewhere) by the idea of salvaging cultures that are visibly disappearing, and primarily under the influence of a wider combination of processes which are often described as modernization, urbanization, industrialization, etc. Within the Croatian context, the notion of salvation (though not expressed by such an explicit syntagm) can be traced back to the end of the nineteenth century and the first, subsequently more systematically developed, attempts to describe and document folk life and folk traditions. ${ }^{8}$ The points, methods, and means of approaching traditional culture, as well as the choice of elements that need to be salvaged - documented, described, but perhaps also truly preserved changed over time and were differentiated, based on their theoretical starting 
points and areas of ethnological and folkloristic activities. However, regardless of these changes, as well as the changing role and status of the salvation project within Croatian ethnology and folkloristics, the idea of salvation has never completely died out and might thus be designated not only as one which marks the beginning of scholarly investigations of (traditional) culture, but also as one which, in a way, presents a permanent feature of our disciplines. With regard to all this, UNESCO's salvation mission (as expected) also fell on fertile ground in Croatia. Even more so, since the Convention for the Safeguarding of Intangible Cultural Heritage which, in truth, is often interpreted or presented as a deviation from the type of salvation based on listing and documenting, lists those same activities among key measures for protection and safeguarding (cf. UNESCO 2003, Art. 2, § 3; Art. 12; Art. 16-17).

In present-day Croatia, the salvation attitude towards culture, especially traditional culture, is perhaps most prominent in various forms of public presentations of folklore, from the UNESCO initiative to folklore festivals, the oldest systematically organised activities of this type. Presenting folklore on stage, similar to presenting folklore on one of the Lists, is regularly (though not always and not exclusively) defined as a form of safeguarding, protecting - in a word, salvaging. Furthermore, this type of salvation is often initiated, promised, undertaken, supervised and at times (if only for promotional purposes) adopted by political, state, international or party agendas and administrations.

There are other similarities between folklore festivals and the UNESCO program. Seeing that they provide a vivid summary of the key points of UNESCO's initiative (especially its implementation), we will discuss these similarities in more detail below.

UNESCO Lists and programs for intangible cultural heritage create a public image of folklore, heritage, tradition, and similar categories, even of subject matters and aims of ethnology and folkloristics, in the same way that folklore festivals have been doing for decades, and continue to do today.

The UNESCO initiative insists on a wide range of practices and living traditions, which serves to emphasize its departure from previous initiatives of this type, including folklore festivals, often aimed at building national culture via performance on stage or some other form of reviving elements that have been recognized as representatives of earlier, traditional culture. However, a more detailed comparison between UNESCO and folklore festivals reveals that differences between them are those of degree rather than type. Although, as has already been noted, the concept of intangible cultural heritage, as defined in the Convention, is wider than the one promoted by folklore festivals (as it includes practices such as craftsmanship, which are only marginally included in folklore festivals in Croatia or even excluded altogether, as well as practices of so-called 
high or urban culture), a significant number of Croatian cultural property inscribed on UNESCO Lists belongs to musical or dance forms (e.g. Bećarac singing and playing, Ojkanje singing, Nijemo kolo - silent circle dance), as well as customary practices (e.g. Ljelje, Zvončari), which have earlier, some even a long time ago, been established as representative within folklore festivals. It should be noted, for instance, that Ojkanje, perhaps the 'most exotic' Croatian element found on UNESCO Lists, attracted possibly the most attention of both experts and the general public, even before World War II (cf. Ceribašić 2003: 153-156). From a historical perspective, the festivals defined a canon that has permeated collective images of folk culture and the legal definition of cultural property, and then went on to shape Croatia's participation in the UNESCO program and Lists.

In sum, what is often nominated to the Lists is previously canonized folklore, while the aforementioned proclaimed distance and break are reduced to little more than ornamental and rudimentary additions to concepts previously established by folklore festivals. In a turn of events, the UNESCO program itself was the theme of the 2010 International Folklore Festival held in Zagreb, Croatia; without too many difficulties and in agreement with its previous practices, this festival transformed elements from the Lists into elements performed on stage, thus reinforcing the impression that the only thing that the UNESCO project brings to the table is a new packaging for things that are familiar and have already been seen. All this leads us to conclude that it would be more appropriate to consider the link between folklore festivals and UNESCO in terms of continuity, that is, expansion, upgrading of existing concepts and practices, as well as re-orientation towards documentation practices, workshops etc., rather than radical departures and twists.

Even the insistence of the UNESCO Convention on living practices, and communities and individuals connected to them, is not very far removed from the focus on so-called authentic folklore which has (with occasional departures or attempts at departures) functioned as the central axis of folklore festivals in Croatia since the 1930s (cf., e.g., Ceribašić 2003; Sremac 2010). Namely, the concept of so-called authentic folklore also assumes that communities present their own, though most frequently once living, collective practices on stage. Within the framework of this concept, village folklore groups perform repertoires that are seen as a characteristic expression of their tradition, which initially signified a radical departure from previous practices copied from urban environments, which is to say practices of village choirs performing authorial compositions based on folk songs. Introducing the concept of so-called authentic folklore also shows signs of opening up at least towards previously living practices, as well as of lending a certain degree of legitimacy to participants in these practices 
(Ceribašić 2003: 187), which are, as has already been mentioned, the levels that UNESCO also insists on. However, after the initial momentum, a performance and genre canon of folklore festivals was established, which at times blocked even explicit attempts to present a wider range of practices rooted in contemporary and everyday life; at the same time lending legitimacy to performers as social subjects with disruptive potential has gradually been downgraded to the sphere of amateurism devoid of wider social pretensions. Along with the canon itself, its effect was transferred into the UNESCO initiative, which is thus, just like the folklore festivals before it, primarily realized as a representational and staged project, at times even with economic potential, usually miles away from living practices or life in communities that UNESCO itself swears by.

In addition to sharing the repertoires and values of folklore festivals, the UNESCO project is similar to them on the level of mechanisms, as well as the goals it is based on. In addition to being among the prominent aims of the Convention (cf. UNESCO 2003, Preamble; Art. 1), safeguarding heritage and encouraging intercultural dialogue are long-standing goals of the International Folklore Festival in Zagreb, as well as numerous similar manifestations (cf. Ceribašić 2008: 9-12). In relation to mechanisms, it is important to point out that national lists of intangible cultural heritage, at least in the Croatian context, function as a kind of antechamber, the first round of selection for nominations to one of the UNESCO Lists, in the same way that the program for the main folklore festival has for decades been selected from the programs of smallerscale festivals (regional, local, preparatory, and others). As has already been noted for folklore festivals (cf. Zebec 2008: 274), Lists also, even in cases when they are not defined as competitive, or even when they, as is the case with the UNESCO Lists, explicitly distance themselves from this status, have strong innate competitive mechanisms. Furthermore, Lists, like folklore festivals, are formed on the basis of external, expert selection, which adds to their competitive dimension.

The final level of similarities between UNESCO initiatives and folklore festivals, which we would like to point out here, refers to participation of ethnologists and folklorists in their realisation. Since the 1930s, Croatian folklorists and ethnologists have taken part in advisory, appraisal or organisational bodies of folklore festivals and, depending on the specific social circumstances, have had a variable, but, taking a long-term view, crucial role both in selecting individual performances and shaping the concept and orientations of festivals in general. They were given a similar role in the process of implementing the UNESCO project in Croatia. But while direct preparation of communities for participation was rare at the inception of folklore festivals (Ceribašić 2003: 81), Croatian nominations to UNESCO Lists were characterised by precisely 
this type of expert involvement. Thus the process within the Croatian context was developed top to bottom: namely, experts were in charge of preparing the necessary application materials, even though the UNESCO Convention is often hailed as the one to make the crucial step towards including the community. Setting aside the question of what community is, what its boundaries are, and who speaks for it, let us stick to the obvious, which is to say the fact that this proclaimed novum of the UNESCO initiative within the Croatian context has manifested itself only within its declarative and decorative dimensions. This is further suggested by the tendency to (at least in the Croatian context) inscribe so-called genres (see, e.g., Zebec 2013), phenomena, and practices on the Lists, which are primarily defined in relation to accepted expert concepts and ambitions of the state administration, and not just concrete practices that individual communities perceive as their own and as specific. Nowadays one might hear that communities themselves tend to demonstrate more and more initiative to nominate elements which they perceive as part of their tradition to one of the UNESCO Lists. However, the question is to what extent the way in which the elaboration might be formulated, i.e., the context in which these elements will be placed as a result of the concept of genres and other administrative-expert frameworks of the nomination, fits the communities' initiative.

The problems of a top-down approach which, among other things, leads to the substitution of local names with generic ones, while practices are grouped into genres which, to an extent, robs the community of its right to its own perspective, are illustrated by the example of Ganga singing and Ojkanje singing. Namely, the Register of Cultural Property of the Republic of Croatia ${ }^{9}$ includes a property called Ganga singing, associated with the 'area of Imotski and Vrgoračka Krajina', which is not under 'UNESCO protection'. ${ }^{10}$ At the same time, as suggested by materials available on the official UNESCO website, ${ }^{11}$ as well as by public reactions, ${ }^{12}$ this form of musical expression is part of the cultural property called Ojkanje singing, which has been inscribed on the UNESCO List of Intangible Cultural Heritage in Need of Urgent Protection. To be sure, the materials for nomination to the UNESCO List do not explicitly use the term Ganga singing, but the description of the musical expression and the sites mentioned suggest that it is also (at least in some of its many variants) included in the nomination. Leaving numerous questions aside, including the issue of who has the right to represent the Croatian Gang ${ }^{13}$ which has been at the centre of public debates in Croatia for some time, as well as the question of why the elaboration of the nomination of Ojkanje singing makes no explicit mention of Ganga singing, let us mention only a few, perhaps exhausting but certainly symptomatic, 'technical problems' of these lists and registers. For instance, the name of the element, "Musical Expression Ojkanje from the Area of the Dalmatian Hinterland", found 
in the Croatian Register, leads one to erroneously conclude that this cultural property is linked to 'the Dalmatian hinterland' alone, when it is in fact - according to that same register and the brief description it includes - also linked to several other Croatian regions. Moreover, the Dalmatian hinterland itself has been included in the register as a separate region (Dalmatian hinterland), with two geographical sites entered separately, as if they did not belong to that same area (although they do). On the other hand, materials available on the official UNESCO website mention the same two sites as part of the Dalmatian hinterland. What is more, the description of that element on the UNESCO website now also includes some areas which are not found in the description of that cultural asset in the Croatian Register. In addition to all this, Ganga singing has been entered into the Register separately and put in a category called "Knowledge and Skills", while Ojkanje singing is found under the heading of "Customs, Rituals and Festivals". In short, in addition to revealing a relaxed situational manner, bureaucratic understatements and contradictions, this mess also (and more importantly) points to the drifting created by the notion that culture can be segmented into intangible cultural property that can be treated just like any other property.

\section{SCHOLARLY PRODUCTION OF HERITAGE VS. SCHOLARLY PRODUCTION OF KNOWLEDGE}

As has already been mentioned, ethnologists and folklorists in Croatia have, from the very beginning, taken part in various activities related to the acceptance and implementation of the Convention for the Safeguarding of Intangible Cultural Heritage by acting, for instance, as members of national and international bodies, developing methods for implementing the Convention, studying intangible cultural practices - potential candidates for inscription onto one of the UNESCO Lists, writing or reviewing nominations for inscriptions on the Lists, etc. Convention-related practice, by which we primarily mean efforts to inscribe elements of intangible cultural heritage onto UNESCO Lists, has for years been quite prominent in Croatia. Since 2009, a total of fourteen cultural elements have been inscribed on two UNESCO Lists: as many as seven in 2009, three in 2010, two in 2011, and one in both 2012 and 2013. In contrast, the number of texts produced in that same period (2009-2013), which provide a critical perspective and view the processes of implementing the Convention from a scholarly perspective, is not very big. With the exception of contributions which make passing, short, descriptive references to the Convention, or assume 
the perspective of application, ${ }^{14}$ we are dealing with a handful of ethnological and folkloristic texts.

One of these texts, written by Naila Ceribašić, was initially published in 2009 under the title "A New Wave of Promoting National Heritage: UNESCO's 'Convention for the Safeguarding of Intangible Cultural Heritage' and its Implementation". Published in Bosnia and Herzegovina in a collection of essays primarily intended for musicologists, this is the first scholarly paper by a Croatian researcher entirely dedicated to the UNESCO initiative. The second text"Culture or Heritage? The Problem of Intangibility" by Lidija Nikočević - was published in the journal of the Croatian Ethnological Society in 2012. In 2010, the Croatian journal Studia ethnologica Croatica published another scholarly article about the Convention: written by Amy Mountcastle, the paper deals with the implementation of the UNESCO program in a different geographical and cultural context. In 2013, a text by Tvrtko Zebec provided an outline of the processes and conflicts of the implementation of the Convention in Croatia from the perspective of participation. Finally, in the same year, all the articles listed above were included in a separate collection entitled Proizvodnja baštine (The Production of Heritage) and edited by Marijana Hameršak, Iva Pleše, and Ana-Marija Vukušić.

As opposed to the rather modest and mostly sceptical domestic scholarly production on the subject of the UNESCO initiative, the public (media) discourse is marked by celebratory overtones and the practices of counting results. From the numerous media reports which have appeared in previous years and which deal with the subject of inscriptions onto the UNESCO List of Intangible Cultural Heritage, one interview published online might be taken as a synecdoche: while discussing Croatian elements of intangible culture, the Deputy of the Croatian Minister of Culture used the following phrase for emphasis: 'Number four in the world, number one in Europe', referring to the fact that (at that moment, of course), compared to other European countries, Croatia had the largest number of intangible cultural elements on UNESCO Lists, and ranked fourth in the world (just after China, Japan, and Korea), based on the same criteria. ${ }^{15}$

If we were to adopt this dominant (and tiresome) public discourse with regard to the UNESCO initiative and decided to 'count' the results, we might, taking as indicators the number of Croatian entries on the UNESCO Lists on the one hand and the number of scientific publications providing criticism or reflection on the Convention and its implementation on the other, get a ratio in which the second number would be several times smaller than the first one. To be sure, this 'sportsmanlike' manner of 'calculating' results is not an appropriate way to view scientific production. In addition, what is under discussion here are 'elements' - entries on the Lists on the one hand, and scientific papers 
on the other - which should be carefully entered into the same equation, not least because the number of properties inscribed on the Lists can be precisely determined, which is not the case with the number of texts that will be accepted as scholarly and critical contributions. Also, scientific musings on any topic cannot even remotely keep up with the variety of practices taking place 'in the field', even the field of UNESCO and implementation. However, the fact that UNESCO has primarily been viewed as a platform for what is tentatively called applied science, and only sporadically as a current social phenomenon, which is to say a subject of scientific interest, provokes our interest. Studying the social dimensions of the UNESCO Convention would also certainly include questions about communities' reactions and expectations, as well as the concrete effects and possible predictions related to some of the nominations, etc. These are questions which undoubtedly require attention, but to which at this moment and within the Croatian context we are unable to provide answers based on specific ethnographic research, as this type of research, at the moment of writing this article, has yet to be conducted.

Meanwhile, an increasing number of researchers in ethnology, folkloristics, and related disciplines are taking part in activities related to the implementation and promotion of the UNESCO Convention. We can only speculate about the reasons behind the disproportion that exists between the level of participation in these activities and that of scientific reflection on the whole process. Commitment to activities focused on inscription onto the UNESCO Lists is hardly surprising, considering the long tradition of applied ethnology and folkloristics in Croatia, which has already been discussed. Perhaps what we are dealing with here is simply the need to do something for the communities that ethnologists and folklorists study as part of their research, and, on the other hand, to contribute to the recognizable quality of intangible culture, and consequently the subject matters of ethnology and folkloristics, in a wider social context - in short, to achieve application of knowledge produced in the scientific process in society, for the benefit of the people the researchers study, and with the presupposed belief in the positive outcomes of the Convention's implementation, despite indications of the contrary. Commitment to this type of involvement - ultimately in the sense of time one has at one's disposal, as well as the different approaches required by (once again, with some qualifications) implementation on the one hand and reflection on the other - may influence the production of scientific writing as well. Furthermore, the social climate in the past years has provided additional stimulus for this type of involvement, since research is nowadays first and foremost expected to be oriented towards producing useful and applicable knowledge, usefulness being very narrowly 
defined in this context, often simply as a state of being connected with the economy, which, in the concrete case of the Convention for the Safeguarding of Cultural Heritage, probably signifies a link with lucrative culture tourism. From the perspective of state administration, applicability can probably also be achieved in the realm of promotional activities designed to supposedly increase the reputation of a national state within its own borders and the world.

This last remark brings us back to the story of the ceremony marking Croatia's entry into the European Union, a celebration which clearly demonstrates the tendency to transform culture into a slick product, which at the same time makes it easier for everyone involved - state administration and experts and those to whom a given cultural practice 'belongs' - to ignore the Potemkin's villages of UNESCO's (or some other) initiatives, as well as to close their eyes to the side effects of the processes discussed here, side effects which, perhaps less visibly, concern society as a whole, and more directly local communities, as well as our specific disciplines and professions. Speaking of our disciplines, and within the context of the aforementioned demands which the media and especially administrations place before researchers and research in our disciplines, the disproportion between routine application and critical reflection in the case of UNESCO brings to mind reflections and anxieties about the future in which ad hoc routine work becomes the key point for evaluating the work of ethnologists and folklorists, while the key dimension of our work as researchers, the one we associate with the value of research, re-examination and criticism, is made redundant amidst a whirlwind of demands and adjustments, becoming an unnecessary ballast which should be abandoned. It is our belief that these values will not disappear, but the question remains within the contexts of which institutions will they be developed and nourished. Speaking of culture, its creative and critical potentials will certainly not disappear, but unfortunately, they are likely to be primarily developed outside, rather than within UNESCO's and other corresponding models for the production of heritage.

Translated by Nada Kujundžić 


\section{NOTES}

1 A somewhat different variant of this text was originally published in Croatian, as an introduction to Proizvodnja baštine: kritičke studije o nematerijalnoj kulturi (The Production of Heritage: Critical Studies on Intangible Culture) (edited by Marijana Hameršak, Iva Pleše, and Ana-Marija Vukušić), a collection of essays published in 2013 by the Institute of Ethnology and Folklore Research in Zagreb.

${ }^{2}$ Here and in the following sentence we quote materials presented at the press conference held on the eve of the celebration of Croatia's entry into the European Union; available at http://www.scribd.com/doc/149148240/HR-EU-prezentacija-za-pressicu-130621, last accessed on 6 November 2018.

3 Cf. UNESCO web page at http://www.unesco.org/culture/ich/, last accessed on 6 November 2018.

4 The questions quoted or paraphrased here are taken from the various and widely distributed Croatian media.

5 See https://ich.unesco.org/en/lists, last accessed on 13 November 2018.

6 Due to the aforementioned discrepancy between the internal laws of Croatia and those of the Convention, some future activist initiative for Croatia to nominate, let us say, the 40-hour work week, public health or free education to one of the UNESCO Lists, would additionally be doomed to 'fail' and be exposed to public scepticism, perhaps even academic cynicism. Naturally, we are not harbouring under the illusion that UNESCO would welcome this type of initiative; we are merely trying to point out that, formally speaking, it would be somewhat harder to disqualify it than it would within the Croatian context, seeing that the 40-hour work week, public health services and free education might be described as 'practices, representations ... that communities, groups and, in some cases, individuals recognize as part of their cultural heritage' (UNESCO 2003, Art. $2, \S 1$ ), which is how UNESCO defines intangible cultural heritage.

7 As far as we know, the first published lecture explaining that the status of monument of culture (and its accompanying principles of preservation) should be granted to 'intangible transmitted heritage' also dates from this period. Published in 1969, the text in question is the work of ethnologist and conservationist Beata GotthardiPavlovsky.

${ }^{8}$ Cf., e.g., a detailed questionnaire about folk life (Osnova za sabiranje i proučavanje grade o narodnom životu 'The Basis for Collecting and Studying Material on Folk Life') composed by the founder of Croatian ethnology Antun Radić; the Call for Collecting Croatian Folk Songs (Poziv za sabiranje hrvatskih narodnih pjesama) issued by the key national institution Matica Hrvatska. Reprints of both texts were published in the 2010 issue of the journal Zbornik za narodni život $i$ običaje (Journal for Folk Life and Customs, volume 55).

9 Cf. the search engine for cultural property of the Republic of Croatia, http://www. min-kulture.hr/default.aspx?id=6212, last accessed on 6 November 2018 . 
${ }^{10}$ See http://www.min-kulture.hr/default.aspx?id=6212, last accessed on 6 November 2018.

${ }^{11} \mathrm{See}$ http://www.unesco.org/culture/ich/doc/download.php?versionID=05434, last accessed on 6 November 2018.

${ }^{12}$ See, e.g., Jendrić (2010), Lucić (2012) and Tomić (2010).

${ }^{13}$ See, e.g., Dragan \& Ćosić (2012), and Lucić (2012).

${ }^{14}$ To illustrate this point, we refer the reader to a few of these texts, for instance, Ceribašić (2009), Jelinčić (2008), Jelinčić \& Žuvela Bušnja (2008), Kalapoš Gašparac (2009), Nikočević (2008), Rudan (2012), Vitez (2007), Zebec (2009, 2012).

${ }^{15}$ Considering the dominant media (and not only media) discourse, it seems important to point out here that the number of properties inscribed on the UNESCO Lists is by no means a measure of the value of culture of a given country. More than anything else, it reveals how well-prepared the state administration and diplomacy are, and to what degree the international community is open towards that country's aspirations. Furthermore, it should be noted that these are not definitive, immutable lists (although some countries have held 'first places' on them for quite some time), but lists that are expanded each year with the addition of new elements. However, it would seem that the UNESCO project also faces limitations typical for similar initiatives and that nowadays it is much more difficult to achieve inscription on one of the Lists than it was at the very beginning. There are numerous possible reasons for this: from a lack of administrative capacities to the belief that the initiative has already been publicly 'recognised'.

\section{REFERENCES}

Aikawa, Noriko 2004. An Historical Overview of the Preparation of the UNESCO International Convention for the Safeguarding of the Intangible Cultural Heritage. Museum International, Vol. 56, No. 1-2, pp. 137-149. https://doi.org/10.1111/ j.1350-0775.2004.00468.x.

Bendix, Regina 2009. Inheritances: Possession, Ownership, and Responsibility. Traditiones, Vol. 38, No. 2, pp. 181-199. DOI: 10.3986/Traditio2009380212.

Bortolotto, Chiara 2009. The Giant Cola Cola in Gravina. Intangible Cultural Heritage, Property, and Territory between Unesco Discourse and Local Heritage Practice. Ethnologia Europaea, Vol. 39, No. 2, pp. 81-94.

Ceribašić, Naila 2003. Hrvatsko, seljačko, starinsko i domaće: Povijest i etnografija jaune prakse narodne glazbe u Hrvatskoj. [Croatian, Peasant, Old and Local: History and Ethnography of the Public Practice of Folk Music in Croatia.] Zagreb: Institut za etnologiju i folkloristiku. 
Ceribašić, Naila 2008. Festivalski okviri folklornih tradicija: Primjer Medunarodne smotre folklora. [Festival Frames of Folklore Traditions: The Example of International Folklore Festival.] In: Zorica Vitez \& Aleksandra Muraj (eds.) Predstavljanje tradicijske kulture na sceni $i$ u medijima. [Presentation of Traditional Culture on the Stage and in the Media.] Zagreb: Institut za etnologiju i folkloristiku \& Hrvatsko etnološko društvo, pp. 7-20.

Ceribašić, Naila 2009. Prilog produkciji baštine: Obnova pojanja u perojskih Crnogoraca. [A Contribution to Heritage Production: Revival of Pojanje among Peroj's Montenegrins.] In: Naila Ceribašić \& Ljiljana Marks (eds.) Izazov tradicijske culture: Svečani zbornik za Zoricu Vitez. [The Challenge of Traditional Culture. Essays in Honour of Zorica Vitez.] Zagreb: Institut za etnologiju i folkloristiku, pp. 309-325.

Dragan, Gordana \& Ćosić, Braco 2012. Imotsku gangu u Parizu pjevat će - Hercegovci!? [People from Hercegovina Will Sing Imotski's Ganga!?]. Slobodna Dalmacija, 25 October. Available at https://www.slobodnadalmacija.hr/scena/mozaik/ clanak/id/183427/imotsku-gangu-u-parizu-pjevat-ce--hercegovci, last accessed on 12 November 2018.

Fawcett, Michelle 2009. The Market for Ethics: Culture and the Neoliberal Turn at UNESCO. Diss. (PhD Thesis). New York University. Available at https://search. proquest.com/docview/304957352/abstract, last accessed on 7 November 2018.

Gotthardi-Pavlovsky, Beata 1969. Folklorna građa i pitanje njene zaštite. [Folklore Materials and Their Protection.] Makedonski folklor, Vol. 3/4, pp. 397-406.

Hafstein, Valdimar Tr. 2007. Claiming Culture: Intangible Heritage Inc., Folklore@, Traditional Knowledge ${ }^{\mathrm{TM}}$. In: Dorothee Hemme \& Markus Tauschek \& Regina Bendix (eds.) Prädikat "HERITAGE": Wertschöpfungen aus kulturellen Ressourcen. Berlin: LIT Verlag, pp. 75-100.

Hameršak, Marijana \& Pleše, Iva \& Vukušić, Ana-Marija (eds.) 2013. Proizvodnja baštine: Kritičke studije o nematerijalnoj kulturi. [Heritage Production: Critical Studies in Intangible Culture.] Zagreb: Institut za etnologiju i folkloristiku.

Jelinčić, Daniela Angelina 2008. Abeceda kulturnog turizma. [ABC of Cultural Tourism.] Zagreb: Meandarmedia/Meandar.

Jelinčić, Daniela Angelina \& Žuvela Bušnja, Ana 2008. Uloga medija u predstavljanju, mijenjanju i kreiranju tradicije. [The Role of the Media in Presenting, Changing and Creating the Tradition.] In: Aleksandra Muraj \& Zorica Vitez (eds.) Predstavljanje tradicijske kulture na sceni $i$ u medijima. [Presentation of Traditional Culture on the Stage and in the Media.] Zagreb: Institut za etnologiju i folkloristiku \& Hrvatsko etnološko društvo, pp. 51-63.

Jendrić, Dorotea 2010. Unesco zaštitio alku, licitarsko srce i "ojkante" della Croazia. [Unesco Protected Alka, Licitarsko Srce and "ojkante" della Croazia]. Večernji list, 17 November. Available at https://www.vecernji.hr/kultura/unesco-zastitio-alkulicitarsko-srce-i-ojkante-della-croazia-216904, last accessed on 12 November 2018.

Kalapoš Gašparac, Sanja 2009. Tradicija na pladnju turizma. [Tradition as Served to Tourism.] In: Naila Ceribašić \& Ljiljana Marks (eds.) Izazov tradicijske culture: Svečani zbornik za Zoricu Vitez. [The Challenge of Traditional Culture: Essays in Honour of Zorica Vitez.] Zagreb: Institut za etnologiju i folkloristiku, pp. 327-335. 
Kirshenblatt-Gimblett, Barbara 2006. World Heritage and Cultural Economics. In: Ivan Karp \& Corinne A. Kratz \& Lynn Szwaja \& Tomás Ybarra-Frausto \& Gustav Buntinx \& Barbara Kirshenblatt-Gimblett \& Ciraj Rassool (eds.) Museum Frictions: Public Cultures / Global Transformations. Durham and London: Duke University Press, pp. 161-202.

Kuutma, Kristin 2013 [2012]. Between Arbitration and Engineering: Concepts and Contingencies in the Shaping of Heritage Regimes. In: Regina F. Bendix \& Aditya Eggert \& Arnika Peselmann (eds.) Heritage Regimes and the State. Göttingen: Universitätsverlag Göttingen, pp. 21-36. Available at https://univerlag.unigoettingen.de/handle/3/isbn-978-3-86395-122-1, last accessed on 7 November 2018.

Labadi, Sophia 2013. UNESCO, Cultural Heritage, and Outstanding Universal Value: Value-based Analyses of the World Heritage and Intangible Cultural Heritage Conventions. Lanham \& New York \& Toronto \& Plymouth, UK: Rowman and Littlefield.

Leimgruber, Walter 2010. Switzerland and the UNESCO Convention on Intangible Cultural Heritage. Journal of Folklore Research, Vol. 47, No. 1-2, pp. 161-196. http://dx.doi.org/10.2979/jfr.2010.47.1-2.161.

Lucić, Predrag 2012. Posljednja ganga u Parizu. [The Last Ganga in Paris.] Novilist.hr, 25 October. Available at http://www.novilist.hr/Komentari/Kolumne/TrafikaPredraga-Lucica/Posljednja-ganga-u-Parizu, last accessed on 7 November 2018.

Matasović, Trpimir 2013. San europske noći. [European Night's Dream.] Zarez.hr, 4 July. Available at http://www.zarez.hr/clanci/san-europske-noci, last accessed on 7 November 2018.

Mezey, Naomi 2007. The Paradoxes of Cultural Property. Columbia Law Review, Vol. 107, No. 8, pp. 2004-2046. Available at https://www.jstor.org/stable/i40002232, last accessed on 7 November 2018.

Milićević, Josip 2009 [1979]. Pretisak teksta o prvih dvadeset godina rada Društva. [Reprint of the Text about the First Twenty Years of Croatian Ethnological Society.] In: Tihana Rubić \& Nevena Škrbić Alempijević \& Željka Jelavić \& Željka Petrović Osmak (eds.) 50 godina Hrvatskoga etnološkog društva (1959.-2009.) [Fifty Years of Croatian Ethnological Society (1959-2009).] Zagreb: Hrvatsko etnološko društvo, pp. 13-32.

Mountcastle, Amy 2010. Safeguarding Intangible Cultural Heritage and the Inevitability of Loss: A Tibetan Example. Studia ethnologica Croatica, Vol. 22, No. 1, pp. 339 359.

Nikočević, Lidija 2008. Zaštita i predstavljanje nematerijalne kulturne baštine. [Protection and Presentation of Intangible Cultural Heritage.] In: Aleksandra Muraj \& Zorica Vitez (eds.) Predstavljanje tradicijske kulture na sceni i u medijima. [Presentation of Traditional Culture on the Stage and in the Media.] Zagreb: Institut za etnologiju i folkloristiku \& Hrvatsko etnološko društvo, pp. 145-151.

Nikočević, Lidija 2012. Culture or Heritage? The Problem of Intangibility. Etnološka tribina, Vol. 42, No. 35, pp. 57-70. Available at https://hrcak.srce.hr/index. php?show=clanak\&id_clanak_jezik=138565, last accessed on 13 November 2018. 
Noyes, Dorothy 2006. The Judgement of Solomon: Global Protections for Tradition and the Problem of Community Ownership. Cultural Analysis, Vol. 5, pp. 27-56. Available at https://pdfs.semanticscholar.org/fac7/55f436ffd03cbc83d2f737d5d2 59dcc112b7.pdf, last accessed on 7 November 2018.

Pofuk, Branimir 2013. Dora Ruždjak Podolski režira svečanost ulaska Hrvatske u EU. [Dora Ruždjak Podolski Is the Director of the Ceremony of Croatia's Accession to EU.] Večernji list, 23 June. Available at http://www.vecernji.hr/vijesti/doraruzdjak-podolski-rezira-svecanost-ulaska-hrvatske-u-eu-clanak-573660, last accessed on 7 November 2018.

Prnjak, Hrvoje 2013. Novogodišnji doček članstva u Europskoj uniji. [New Year's Celebration of Membership in European Union.] Slobodna Dalmacija, 2 July. http://www.slobodnadalmacija.hr/Reflektor/tabid/92/articleType/ArticleView/ articleId/214632/Default.aspx, no longer available.

Rihtman-Auguštin, Dunja 1982. Zaštita folklore: Akcija i problemi. UNESCO - Pariz 1982. [Folklore Protection: Action and Problems. UNESCO - Paris 1982.] IEF ms. 1611.

Rihtman-Auguštin, Dunja 1984. Trideset i pet godina rada Zavoda za istraživanje folklora. [Thirty-Five Years of Department for Folklore Research.] Narodna umjetnost, Vol. 21, pp. 11-33. Available at https:/hrcak.srce.hr/45637, last accessed on 7 November 2018.

Rudan, Evelina 2012. Verbalni folklor i njegova (re)prezentacija. [Verbal Folklore and Its (Re)presentation.] In: Mira Muhoberac (ed.) Međunarodni znanstveni interdisciplinarni simpozij "Hrvatska folklorna $i$ etnografska baština u svjetlu dubrovačke, sujetske i turističke sadašnjosti - FEB 2011”. Zbornik radova. [International Interdisciplinary Scholarly Conference of Croatian Folklore and Ethnographic Heritage in the Light of the Dubrovnik, World and Tourist Presentthe FEB 2011]. Dubrovnik: Folklorni ansambl Linđo, pp. 509-519.

Smith, Laurajane 2012. Discourses of Heritage: Implications for Archaeological Community Practice. Nuevo Mundo Mundos Nuevos / New World New Worlds. Questions du temps présent. DOI: 10.4000/nuevomundo.64148.

s. n. [Turčin, Vesna] 1986. Institucije koje skupljaju i čuvaju građu o tradicijskoj kulturi i folkloru u SR Hrvatskoj. Izvanredni svezak, knj. 8. [Institutions Which Collect and Archive Traditional Culture and Folklore Materials. Special Volume, 8.] Zagreb: Zavod za istraživanje folklora.

Škrbić Alempijević, Nevena \& Oroz, Tomislav 2009. Mijene etnoloških pristupa i metoda. [Transformations of Approaches and Methods in Ethnology.] In: Tihana Rubić \& Nevena Škrbić Alempijević \& Željka Jelavić \& Željka Petrović Osmak (eds.) 50 godina Hrvatskoga etnološkog društva (1959.-2009.) [Fifty Years of Croatian Ethnological Society (1959-2009).] Zagreb: Hrvatsko etnološko društvo, pp. 65-87. Available at http://www.hrvatskoetnoloskodrustvo.hr/wp-content/ uploads/2012/11/Spomenica-HED-a.pdf, last accessed on 9 November 2018.

Sremac, Stjepan 2010. Povijest i praksa scenske primjene folklornog plesa u Hrvata: Između društvene $i$ kulturne potrebe, politike, kulturnog $i$ nacionalnog identiteta. [The History and Practice of Application of the Traditional Dance on the Stage among Croats: Between Social and Cultural Necessity, Politics, Cultural and National Identity.] Zagreb: Institut za etnologiju i folkloristiku. 
Tsitsishvili, Nino 2009. National Ideologies in the Era of Global Fusions: Georgian Polyphonic Song as a UNESCO-Sanctioned Masterpiece of Intangible Heritage. Music \& Politics, Vol. 3, No. 1. http://dx.doi.org/10.3998/mp.9460447.0003.104.

Tomić, Ante 2010. Ooo-o-o-o! Ooo-o-o-o-oooj! Jutarnji list, 20 November. Available at http://www.jutarnji.hr/ante-tomic--ooo-o-o-oooj-/905432/, last accessed on 9 November 2018.

Turčin, Vesna 1982-1986. Dokumentacijska građa uz projekt "Regionalni registar institucija koje skupljaju i čuvaju građu o tradicijskoj kulturi i folkloru u SFR Jugoslaviji", 1982-1986. [Documentary Materials of the Project "Regional Register of Institutions That Collect and Archive Traditional Culture and Folklore Materials in SFR Yugoslavia", 1982-1986.] IEF ms. 2038.

UNESCO 1972 = Convention Concerning the Protection of the World Cultural and Natural Heritage. Available at http://whc.unesco.org/en/conventiontext/, last accessed on 2 November 2018.

UNESCO 1989 = Recommendation on the Safeguarding of Traditional Culture and Folklore. Available at http://portal.unesco.org/en/ev.php-URL_ID=13141\&URL_ DO=DO_TOPIC\&URL_SECTION=201.html, last accessed on 2 November 2018.

UNESCO 2003 = Convention for the Safeguarding of the Intangible Cultural Heritage. Available at https://ich.unesco.org/en/convention, last accessed on 13 November 2018.

Vitez, Zorica 2007. Legenda o Picokima u svjetlu globalne i nacionalne (kulturne) politike. [The Legend of the Picoks in the Light of Global and National (Cultural) Policy.] Narodna umjetnost, Vol. 44, No. 2, pp. 11-25. Available at https://hrcak. srce.hr/23263, last accessed on 9 November 2018.

Zakon 1999 = Zakon o zaštiti $i$ očuvanju kulturnih dobara. [Act on Protection and Safeguarding of Cultural Goods.] Available at http://narodne-novine.nn.hr/clanci/ sluzbeni/271022.html, last accessed on 9 November 2018.

Zakon 2005 = Zakon o potvrdivanju Konvencije o zaštiti nematerijalne kulturne baštine. [Act on the Ratification of the Convention for the Safeguarding of the Intangible Cultural Heritage.] Available at http://narodne-novine.nn.hr/clanci/ medunarodni/327387.html, last accessed on 9 November 2018.

Zebec, Tvrtko 2008. Izazovi primijenjene folkloristike i etnologije. [Challenges of Applied Folklore Studies and Ethnology.] In: Zorica Vitez \& Aleksandra Muraj (eds.) Predstavljanje tradicijske kulture na sceni $i$ u medijima. [Presentation of Traditional Culture on the Stage and in the Media.] Zagreb: Institut za etnologiju i folkloristiku \& Hrvatsko etnološko društvo, pp. 271-286.

Zebec, Tvrtko 2012. Kultura - tradicija - baština - turizam: Dubrovnik i Hrvatska u dvadeset i prvome stoljeću. [Culture - Tradition - Heritage - Tourism: Dubrovnik and Croatia in the 21st Century.] In: Mira Muhoberac (ed.) Medunarodni znanstveni interdisciplinarni simpozij "Hrvatska folklorna i etnografska baština u svjetlu dubrovačke, svjetske i turističke sadašnjosti-FEB 2011”. Zbornik radova. [International Interdisciplinary Scholarly Conference of Croatian Folklore and Ethnographic Heritage in the Light of the Dubrovnik, World and Tourist Presentthe FEB 2011.] Dubrovnik: Folklorni ansambl Linđo, pp. 503-507. 
Zebec, Tvrtko 2013. Etnolog u svijetu baštine: Hrvatska nematerijalna kultura u 21. stoljeću. [Ethnologist in the World of Heritage: Croatian Intangible Cultural Heritage in the 21st Century.] In: Jasna Čapo \& Valentina Gulin Zrnić (eds.) Hrvatska svakodnevica: Etnografije vremena i prostora. [Croatian Everyday Life: Ethnographies of Time and Space.] Zagreb: Institut za etnologiju i folkloristiku, pp. 173-195. 